Studia nad Autorytaryzmem i Totalitaryzmem 43, nr 1

Wrocław 2021

https://doi.org/10.19195/2300-7249.43.1.10

\author{
JUSTYNA PRZEDAŃSKA \\ ORCID: 0000-0002-3558-3969 \\ Uniwersytet Wrocławski \\ justyna.przedanska@uwr.edu.pl
}

\title{
The faces of freedom in the concepts of a liberal and non-liberal state
}

\begin{abstract}
The last decade has exposed the recession of freedom throughout the world. It arises from the latest Freedom in the World 2020 report that civil liberties and political rights have deteriorated in 64 countries, while only 37 have seen a slight improvement in these areas. The principles of liberal democracy (the rule of law, free elections, minority rights and freedom of expression) in Europe, historically the best-performing region in terms of freedom in the world, have come under serious pressure in recent years.

In the article, starting from an analysis of the categories of freedom presented in many aspects, followed by a discussion of the assumptions and concepts of liberalism, as well as the political project referred to as non-liberal democracy, which has grown out of their criticism, the author identifies the problem of instrumentalization and relativization of freedom, which leads to the restriction of freedom of speech, freedom of minorities, religious freedom and sexual freedom, replacing the individual freedoms of the citizens with the so-called collective freedom.
\end{abstract}

Keywords: freedom, democracy, liberalism, non-liberal democracy, authoritarianism.

\section{Introduction}

The rhetorical charm of the idea of freedom is so great that various, even extreme, political philosophies admit to freedom; equally Liberals and Libertarians or Republicans and even Marxists claim to be the only true defenders of freedom. ${ }^{1}$ That is why many researchers willingly take up the issue of personal and political

${ }^{1}$ Ch. Kukathas, "Wolność", [in:] Przewodnik po współczesnej filozofii politycznej, eds. R.E. Goodin, P. Pettit, Warszawa 1998, p. 690. 
freedom $^{2}$ and try to redefine this idea. Constitutive elements, which make up the category of freedom, can be distinguished among the components of the various definitions, although the way in which it is defined is always conditional on the research perspective adopted.

However, the problem turns out to be not that the representatives of various political concepts would like to attribute to themselves the exclusive right to use freedom, but for other objectives or values, specific political projects relativize, instrumentalize or destroy the freedom, which would appear to be fundamental and inalienable for everyone. In the light of the above, the question can be asked as to whether countries with a democratic system can function in today's realities, intentionally giving up protection of the freedom of their citizens, protection of the freedom of minorities and protection of religious or sexual freedoms. This article first considers the point of view of how freedom can be viewed and from what perspectives it can be defined. It then describes a liberal state by presenting some of the most popular, most characteristic and most important concepts about the idea of liberalism. Thirdly, it discusses the essence of a non-liberal democracy, which is key to answering the problem presented and the research question posed, and in particular the relationship between individual freedom and so-called collective freedom, related to the negation of the assumptions of liberalism, which, paradoxically, poses a threat to citizenship in a subjective sense.

\section{The essence of freedom}

The category of freedom can be viewed in many ways. The idea of freedom can be analysed from the point of view of the matter of free will, around which there has been a dispute between determinism and indeterminism for centuries. ${ }^{3}$ The question is whether human acts are determined by their causes (and the overall conditions), whether they are subject to laws like other phenomena, or whether they are free, and therefore, there are no causes that would determine them. ${ }^{4}$ According to the determinists, if human acts are determined by natural causes, there are no grounds for attributing responsibility to them, and therefore there is no phe-

2 Cf. e.g.: Q. Skinner, “The paradoxes of political liberty”, [in:] Liberty, ed. D. Miller, Oxford 1991; P. Pettit, The freedom of the city: a republican ideal, [in:] The Good Polity. Normative Analysis of the State, eds. A. Hamlin, P. Pettit, Oxford 1989; E. Fromm, Ucieczka od wolności, Warszawa 2014; M. Friedmann, Free to Choose, New York 1980; J. Gray, "On positive and negative freedom", [in:] Conceptions of Liberty in Political Philosophy, eds. J. Gray, Z. Pełczyński, London 1984; T. Gray, Freedom, London 1990.

${ }^{3}$ See: Determinizm, przypadek, wolność, ed. A. Wójtowicz, Poznań 2005; K. Śleziński, "Determinizm i indeterminizm w dyskusji metanaukowej połowy XX wieku", Bielsko-Żywieckie Studia Teologiczne 4, 2003, pp. 301-310; S. Amsterdamski, "O różnych pojęciach determinizmu”, Studia Filozoficzne 2, 1964.

4 Filozofia a nauka. Zarys encyklopedyczny, Wrocław 1987, p. 87. 
nomenon of free will. This, in turn, contrasts with the indeterministic position, the most extreme face of which is existentialism. According to Jean-Paul Sartre, for example, human acts are completely free, while man himself takes responsibility for them, which implies that his behaviour needs to be assessed exclusively from a moral point of view, because freedom means there is no natural or social need that would bind man in his conduct. ${ }^{5}$

Freedom can also be seen from the point of view of its forms and its actual or normative, transgressive or impassable, external or internal limits, ${ }^{6}$ which is decidedly a subject for a separate study in theoretical terms. In this respect, Hiller Steiner, for example, controversially claims that freedom should be construed as a fixed amount that is not subject to the laws of physics (expansion, contraction or reduction); it can only be redistributed. While trying to imagine this, it can be said that, if one person loses his freedom (or its part), for instance, as a result of serving a sentence in a prison, then some other person has automatically gained more freedom. ${ }^{7}$

Additionally, freedom can also be analysed by dividing 8 it into freedom 'to' and freedom 'from'. Freedom conditioned by such a division (referring to some extent to Aristotle's concept) was proposed by Isaiah Berlin, who took the issue of coercion as a basis to distinguish two types of freedoms: negative freedom, defined as freedom from external constraints, ${ }^{9}$ and positive freedom, defined as the ability of self-determination and self-fulfilment. ${ }^{10}$ By making this distinction, Berlin gave primacy to a negative view of freedom, ${ }^{11}$ which he identified with eliminating or at least limiting interventions in the person's individual space which are

5 Filozofia a nauka..., p. 91; J.P. Sartre, "Absolutna wolność bytu ludzkiego”, [in:] Filozofia egzystencjalna, eds. L. Kołakowski, K. Pomian, Warszawa 1965. For the notion of man "condemned to freedom' in the concept of existentialism, see: W. Tatarkiewicz, Historia filozofii, vol. 3, Warszawa 2003, pp. 351-353.

6 J. Acton, Historia wolności. Wybór esejów, Kraków 1995; W. Lamentowicz, O wolnościach i ich granicach, http://www.academia.edu/1136811/Granice_wolności (accessed: 10.12.2020).

${ }^{7}$ H. Steiner, "How free: Computing personal liberty", [in:] Of Liberty, ed. A. Phillips Griffiths, Cambridge 1983, pp. 87-89.

8 Although there are also those who claim that freedom is indivisible, such as Michał Bakunin, who claimed that a person cannot be deprived of any part of his freedom without depriving him of freedom at all; see: M.A. Bakunin, Pisma wybrane, vol. 1 and 2, Warszawa 1965.

9 It is characterized by the answer to the question of where, within what limits, an individual has or should have complete freedom to be and act according to their own will.

${ }^{10}$ It is characterized by the answer to the question of who or what is considered to be the source of authority or coercion that makes the individual take such action as opposed to any other. Cf. I. Berlin, Four Essays on Liberty, Warszawa 1994, pp. 185-194; S. Mrozowska, "Wolność negatywna w warunkach demokracji liberalnej”, [in:] Paradoksy liberalizmu, eds. D. Karnowska, A. Modrzejewski, Toruń 2009.

11 Cf. A. Chmielewski, Dwie koncepcje jedności. Interwencje filozoficzno-polityczne, Wroclaw 2006, pp. 17-24. 
not desirable by that person. ${ }^{12}$ Close positive freedom was the participatory freedom ${ }^{13}$ proposed by Benjamin Constant, which he compared to freedom 'from'. B. Constant believed that private (personal) freedom is the sine qua non of public freedom and not vice versa, and therefore, private freedom should be defended against state interference.

Furthermore, the category of freedom can be perceived from the point of view of the relationship of one individual to another individual and the relationship of the individual to the community. The way an individual's and society's relationship with the state is seen depends on other views about society, constituting the subject of the traditional dilemma of social and political philosophy: "the individual or the community?", ${ }^{14}$ which, in principle, boils down to a dispute between the liberal approach to individualism and the communitarian concept of a community. Accepting this point of view, it can be said that the liberal approach is directed at individualism. The liberal model of society is characterized by the following attributes: firstly, it is the individual and not the community that constitutes the ontological foundation of society; secondly, there is a separation between the state and society, where society, consisting of empowered individuals, is a sphere of freedom (including economic), a (public) space that is independent of the state, which is situated between the state (which is supposed to safeguard peace and or-

12 And since philosophical disputes do not die, most often feeding only on themselves, it can already be mentioned for information purposes that, according to Gerard MacCallum, I. Berlin's distinction is fundamentally incorrect because there is only one concept of freedom, namely one freedom. This concept encompasses covers both the positive aspect (freedom 'to') and the negative aspect (freedom 'from'). G. MacCallum's Triadic model of the concept of freedom presents the following formula: agent $\mathrm{X}$ is free of constraint $\mathrm{Y}$ to be able to do or to be $\mathrm{Z}$, which is his Objective - cf. G.C. MacCallum, "Negative and positive freedom", The Philosophical Review 3, 1967.

13 He defined participatory freedom like Athenian democracy, about which he wrote as follows: "Ostracism, self-governance that has been legalized and praised by all the legislators of the time, ostracism, that appears and should appear to us to be an outrageous injustice, proves that the individual in Athens was subordinated to the supremacy of the social body to an extent that does not exist in any of the free countries of Europe" [own translation] - see B. Constant, O monarchii konstytucyjnej i rękojmiach publicznych, Warszawa 2016, p. 177.

14 See: M. Turowski, Liberalizm po komunitaryzmie? Filozoficzne koncepcjejednostki, wspólnoty i państwa jako źródła krytyki spolecznej i politycznej, Toruń 2011. In turn, when referring to this distinction, Adam Chmielewski suggests that the axis of the dispute, namely the opposition, should be set differently: "an open society or community?" (which is discussed in the fourth part of this article). He writes that "This is because the fundamental problem of this concept is not whether the organization of social life should be based on the assumption of ontological primacy of the individual or the community [...] but on whether the political community should be organized in order to create such a public space as will favour the egalitarian objective of developing the individual subjectivity of all of its members, or vice versa: such space in which the development of the individual subjectivity of people will be subordinated to the supra-individual political objectives of the community to which they belong"' - A. Chmielewski, Spoleczeństwo otwarte czy wspólnota? Filozoficzne i moralne podstawy nowoczesnego liberalizmu oraz jego krytyka we współczesnej filozofii politycznej, Wrocław 2001 [own translation]. Cf. A. Szahaj, "Jednostka czy wspólnota", [in:] Liberalizm u schyłku XX wieku, ed. J. Miklaszewska, Kraków 1999. 
der) and the individual; thirdly, voluntary communities (associations and social organizations) founded by individuals on formal grounds (not only community ties) operate within this space, through which individuals can also pursue their goals. ${ }^{15}$

In turn, community thought is presented by the classical republican tradition, to which such features can be attributed as, firstly, that the concept of society is ontologically based on the community and its good; secondly, the individual is seen from the point of view of the community, for whom good is or should be its primary objective; thirdly, there is no separation between society and the state (institutional or ethical); and fourthly, citizens forming a community always interact with and identify with the state. ${ }^{16}$ In principle, communitarianism can be seen as a negative 'concept', in the sense that it has grown out of a criticism of the assumptions of liberalism. However, as a movement, it does not present a single doctrine specifying the vision of the state, which would be built on a coherent and methodical basis, an attribute appearing in the theses of individual representatives is, in a way, the sanctioning of the needs of the community as primordial (more important) to the needs of the individual. ${ }^{17}$ This movement, referred to in this way, is a young one; it has grown out of the egalitarian criticism of the concept proposed by John Rawls in A Theory of Justice (Amitai Etzioni took it up in the broadest sense), as well as the libertarian concept, which is most fully expressed in Robert Nozick's book Anarchy, State, and Utopia. However, it is worth emphasizing that the communitarian assumptions ${ }^{18}$ are firmly rooted in the philosophical tradition; such a distinction was sometimes already made as early as by Plato or Aristotle. ${ }^{19}$ The representatives of communitarianism include Jean Jacques

15 D. Pietrzyk-Reeves, Idea społeczeństwa obywatelskiego. Wspótczesna debata i jej źródła, Wrocław 2004, pp. 57-116; Z. Rau, Zapomniana wolność. W poszukiwaniu historycznych podstaw liberalizmu, Warszawa 2008; L. Morawski, Główne problemy współczesnej filozofii prawa. Prawo w toku przemian, Warszawa 2005, pp. 167-174.

16 According to D. Pietrzyk-Reeves, these traditions are different, but not opposites to each other because, in a way, the liberal tradition grows out of the republican tradition. Cf. D. Pietrzyk-Reeves, Idea spoleczeństwa..., pp. 17-56; J. Przedańska, "Społeczeństwo obywatelskie jako idea filozoficzna", [in:] Prawna działalność instytucji społeczeństwa obywatelskiego, eds. J. Blicharz, J. Boć, Wrocław 2009, pp. 13-22.

17 For more on the dispute between liberalism and communitarianism, see: J. Przedańska, "Równość w wolności — między komunitaryzmem a liberalizmem", [in:] Wolność w prawie administracyjnym, ed. J. Zimmermann, Warszawa 2017, pp. 31-54.

18 More: Ł. Dominiak, Wartość wspólnoty. O filozofii politycznej komunitaryzmu, Toruń 2010; H.B. Tam, Komunitaryzm. Nowy program polityczny i obywatelski, Torun 2011.

19 When defining man as a social being, Aristotle simultaneously described him as a political and civil being. The Greek adjective politike (politikos, politikon) simply means 'civic', 'state', 'public', 'observing the social order', 'capable of dealing with public affairs'. In turn, the verb politeuo, which disappeared from the language with the fall of the Hellenic polis, meant: "I am a citizen who governs his country". More Z. Kowalewski, "Społeczeństwo obywatelskie a 'politeia' i 'res publica"', Studia Filozoficzne 9, 1987, pp. 7-49; Aristotle, Polityka, [in:] idem, Dzieła wszystkie, vol. 6, Warszawa 2001. 
Rousseau, ${ }^{20}$ George W.F. Hegel, who recognizes the primacy of the state over the individual, ${ }^{21}$ Charles Taylor, who believes that man does not come into the world as an individual equipped with identity, freedom and inalienable rights, that he is not an independent subject of ethical conduct, that every human is only given all this when he exists in the community, in society, it is then that he is constituted as an holder of rights and freedoms ${ }^{22}$; or, finally, Alasdair MacIntyre, who believes that the moral freedom of the individual, typical of the liberal doctrine, which does not refer to the idea of the common (public) good, is the cause of the atomization of societies and the disintegration of social ties, cultural and religious values and community virtues. ${ }^{23}$

\section{A liberal vision of the state}

Liberalism, as a political concept, emerged in the 19th century, but liberal ideas are much older. Generally speaking, liberalism is a political ideology for which freedom in all its dimensions is an overriding and primordial value. Liberalism refers to the concept of a state which has limited power and functions, which realizes democratic values, valuing private property, the free market and civil rights. A liberal state opposes an absolute state on the one hand and a social state on the other. ${ }^{24}$

The origins of the liberal doctrine are inextricably linked to John Locke, who was one of the first philosophers to stop seeing society (like Thomas Hobbes) as a natural creation of the community, defining it as the result of a social contract created by the consent of individuals; a social contract is primarily made to protect life, freedom and property. This concept assumes the ontological primacy of the individual, who makes up society, and then also the state (the state arises as a re-

${ }^{20} \mathrm{He}$ believed that the values of freedom should be experienced by every citizen, while the main objective of citizens should be to create a free society, namely, a society in which citizens, if they are equal (postulate of egalitarianism) and simultaneously enlightened, and therefore aware of their own social role, should be active in public space. However, in a situation where citizens are not interested in state and social matters, they themselves voluntarily give up their own (civic, after all) freedom — see J.J. Rousseau, Umowa społeczna, Łódź 1948; J. Szacki, “Od polis do społeczeństwa obywatelskiego”, [in:] J. Szacki, Historia myśli socjologicznej, Warszawa 2005, pp. 91-95.

21 Ś.F. Nowicki, "Heglowskie pojęcie społeczeństwa obywatelskiego", Studia Filozoficzne 9, 1987, pp. 51-80; M.J. Siemek, Hegel i filozofia, Warszawa 1998.

${ }_{22}$ Cf. Ch. Taylor, Etyka autentyczności, Kraków 1996; A. Chmielewski, Dwie koncepcje jedności..., p. 64.

23 A. MacIntyre, Dziedzictwo cnoty. Studium z teorii moralności, Warszawa 1996; J. Zdybel, Między wolnościa a powinnością. Filozofia polityczna Isaiaha Berlina i Alasdaira MacIntyre'a, Lublin 2005.

24 More: Ł. Rozen, Liberalizm i demokracja jako fundamentalny dylemat wspótczesnej polityki, [in:] Zmierzch demokracji liberalnej?, eds. K.A. Wojtaszczyk, P. Stawarz, J. Wiśniewska-Grzelak, Warszawa 2018, pp. 106-115. 
sult of the union of society and government). ${ }^{25}$ The results of a social contract are two forms of society: a civic society, where people organize themselves, associate to achieve objectives that are important in terms of their particular aims, which arise from exercising their natural rights, and a political community in which individuals can become citizens by making individual choices of authorities and exercising their rights. ${ }^{26}$

John S. Mill proposed a basic framework of the liberal approach, claiming that no other value should be as important in a person's life as freedom; without it, other values cannot fully materialize. Taking freedom as a fundamental value, Mill proposed an extensive list of freedoms in which, in addition to the right to property, he listed almost all the freedoms codified today, such as personal and political freedoms, with freedom of speech, conscience, freedom of association, but also, for example, freedom of taste and freedom of self-determination. Mill's attitude is best illustrated by his words:

If all mankind minus one, were of one opinion, and only one person were of the contrary opinion, mankind would be no more justified in silencing that one person, than he, if he had the power, would be justified in silencing mankind. [...] neither one person, nor any number of people is warranted in saying to another human adult that he shall not do with his life for his own benefit what he chooses to do with it. ${ }^{27}$

In turn, Immanuel Kant inextricably linked the category of freedom with the category of duty, claiming that the basis of political freedom, as well as the basis for choosing a particular action and behaviour, is the ethical duty. ${ }^{28} \mathrm{He}$ wrote that the free will to act is determined by the duty to do so, adopting the principle that you can do something, because you should do it. How far removed is this from the dominating attitude in the liberal trend, which, after all, is dominated by an assumption that is deprived of the rule of duty, in the spirit of the principle: you can do something because you want to do it and it is not prohibited. Since, in the case of Kant, freedom is conditioned by an ethical duty, an individual can achieve moral status by making such choices which are in compliance with the dictates of pure and unconditioned will. Furthermore, Kant's idea places the individual in a kind of "universe of abstract freedom, where making sovereign decisions is a matter of transforming a specific individual into a pure moral subject, and where even doing

25 J. Locke, “Traktat drugi”, § 87, [in:] Dwa traktaty o rzadzie, Warszawa 1992, p. 222.

26 J. Przedańska, "Społeczeństwo...”, pp. 13-22. On J. Locke’s concept, see: J. Szacki, “Od polis do społeczeństwa...”, pp. 60-71; B. Hindess, Filozofie wladzy. Od Hobbesa do Foucaulta, Warszawa 1999, pp. 27-81.

27 J.S. Mill, Utylitaryzm. O wolności, Warszawa 1959, pp. 133, 139, 226; L. Morawski, Gtówne problemy..., pp. 170-171.

28 Cf. I. Kant, Krytyka praktycznego rozumu, Warszawa 2004; M. Żelazny, Idea wolności w filozofii Kanta, Toruń 2001; W. Tatarkiewicz, op. cit., pp. 177-179. 
evil, if not forced and voluntary, lies within his own notion of morality". ${ }^{29}$ Among the attributes of citizenship, Kant included freedom, namely being subject to the laws to which the citizens have given their consent, as well as civic equality and civic self-sufficiency. For Kant, the state (namely a community of citizens) meant primarily a legal community, the fundamental objective of which was to protect civic rights. He introduced the category of a state of public justice, namely formal (legal) justice; without simultaneously comparing the sphere of society as a state. In turn, he considered public space as an area that distinguishes and simultaneously unites society and the state. ${ }^{30}$

One of the clearer representatives of liberalism is Friedrich Hayek, who openly said that "if a liberal were to choose between liberal autocracy and illiberal democracy, he should choose the former, because from the point of view of liberalism, whether power belongs to the majority or the minority it is not as important as whether it upholds the freedom of its citizens or not". ${ }^{31}$ Hayek inextricably relates freedom with responsibility, emphasizing that being a free (and responsible for that freedom) citizen, namely a member of a social community, generates an exceptional status, because, on the one hand, it gives rise to rights (constitutes a privilege) and, on the other, to obligations (a burden). Therefore, a system that guarantees citizens the ability to be fully free to express their views and to seek, check or test themselves and their needs - naturally, within the limits of the law provides citizens with the prospect of self-fulfilment, while making the whole of society capable of greater development and creativity. In summary, Hayek argues that the freedom of the individual determines the social well-being of a society.

Freedom, which is seen as the absence of coercion from other people, as liberal ideas proclaim, should be an inherent value for every human. ${ }^{32}$ According to this argument, freedom can only be limited by acts that are coercive: freedom violates the coercion applied by others. However, coercion cannot be completely eliminated because, paradoxically, the only way to counteract coercion is to threaten it. However, by concluding a social contract, a free, democratic society has overcome this problem by handing over the monopoly of coercion to the state. Naturally, this coercion must be deprived of its most harmful effects by reducing it to a minimum; this means that, apart from situations of which he is aware in advance because they arise from the principles of the law, an individual should not actually experience coercion. ${ }^{33}$

29 P. Przybysz, "Dwa modele człowieka. O sporze liberalizm-komunitaryzm”, Arka 3, 1994, pp. 16-17 [own translation].

30 Cf. J. Przedańska, "Społeczeństwo...", pp. 13-22.

31 F.A. von Hayek, Konstytucja wolności, Warszawa 2006, p. 103 [own translation]; G. Jeż, "Idea sprawiedliwości społecznej jako kamuflaż sprawiedliwości rozdzielczej i jej krytyka w myśli Friedricha Augusta von Hayeka", Kwartalnik Historii Myśli Ekonomicznej 1, 2014.

32 More in B. Polanowska-Sygulska, Oblicza liberalizmu, Kraków 2003, p. 12 ff..

33 Therefore, which is particularly important, in principle, Hayek does not include rights among the factors limiting freedom; F.A. von Hayek, Konstytucja wolności..., pp. 34-35. 
Similarly, at least in this respect, the idea is being formed by one of the more extreme liberals, Robert Nozick, who claims that the actions of people who behave in accordance with their rights (legally) do not interfere with or restrict the freedom of others. Chandran Kukathas presented this very visually, writing,

So if, as a result of others acting within their rights, I am left with the choice of working for Robert Maxwell or starving I cannot claim that I am forced or coerced into involuntary employment. If, however, Mr Maxwell had engineered this situation (say, by stealing from and bankrupting his competitors) I can claim to have been forced. ${ }^{34}$

It is worth mentioning, for example, John Rawls' concept, which is that, when they are in the situation of a social contract, individuals have the ability to make free choices. Based on rational premises, they can arrive at principles of justice. The principle of the primacy of freedom provides that each individual has the right to the greatest possible scope of his own freedom, which is compatible with similar freedoms of other individuals. It transpires from this principle that an individual's freedom can only be restricted because of the need to protect the similar freedom of another individual or individuals. This means that individual freedoms cannot be regarded as a basis of political or social bargaining. "Neither because of financial prosperity, economic and social benefit, nor because of the efficiency of our institutions, can it justify a restriction of freedom. Freedom is therefore an individual's advantage in the game with the state." 35

In summary, the atomic concepts of liberalism, which are so typical of Locke, Rawls, Hayek and Nozick, ${ }^{36}$ focus on the arrangement of orderliness of the state so that the ideas of the freedom of individuals, including the right to decide freely about oneself, the right to choose freely to participate in social life ${ }^{37}$ or the nature of private life, were his orientation and foundation. Therefore, the task of citizens coexisting in public space should be to strive to ensure that they have as many of these freedoms as possible, which will be protected by law. A unique paradox can be seen here: a liberal vision of state order is most frequently identified with a lack of interference (negative freedom in Berlin's opinion), in principle, assuming the minimum involvement of the state in public, social and economic life, but, on the other hand, the most important value for the ideals of liberalism is freedom

34 See: R. Nozick, Anarchia, państwo, utopia, Warszawa 1999; Ch. Kukathas, "Wolność", pp. 690-691.

35 L. Morawski, Główne problemy..., p. 170; J. Rawls, Teoria sprawiedliwości, Warszawa 2009; G.W. Sienkiewicz, Egalitaryzm demokratyczny. Podstawy teorii sprawiedliwości Johna Rawl$s a$, Torun 2008 [own translation].

${ }^{36}$ Robert Nozick supported the vision of a minimum state and described his own views as libertarian. He wrote that 'individuals have rights and there are things that no person or group can take away from anyone without breaching their rights' - R. Nozick, op. cit., p. 5.

37 Cf. R. Wonicki, Spór o demokratyczne państwo prawa. Teoria Jürgena Habermasa wobec liberalnej, republikańskiej i socjalnej wizji państwa, Warszawa 2007, pp. 44-54. See also: R.M. Unger, Ruch studiów krytycznych nad prawem, Warszawa 2005, p. 112. 
and its limitation wherever possible, namely broadening the sphere of individual freedom with respect to the public authority. If that is the case, then, in a democratic state with liberal overtones, ${ }^{38}$ there should be as many such regulations on the fundamental freedoms of citizens as possible and they should be as broad as possible.

\section{A non-liberal vision of the state}

The relationship or association between freedom and democracy, and therefore liberalism - making freedom per se a reality — and democracy, ceased to be so obvious some time ago. Although for years there has been a communis opinio doctorum that a democratic system is inextricably linked to liberalism, ${ }^{39}$ it is, after all, not the only alliance that democracy can form.

According to Hubert Izdebski, liberal democracy should not be identified with liberal democracy, because this is an appearance of the original source of liberal democracy, i.e. the philosophical trend born during the Enlightenment, which benefited from the demands of the fight for human freedom. ${ }^{40}$ Friedrich Hayek also comes to similar conclusions, noting that democracy is a system and simultaneously a concept that legitimizes power, while liberalism is a guarantee of the restriction of authority in favour of the freedom of individuals. ${ }^{41}$

Norberto Bobbio presented an interesting scheme of relations between democracy and liberalism, stating that three types of relations can be distinguished: firstly, democracy and liberalism are concurrent, which means that it is possible for a democratic-liberal state, a liberal-non-democratic state and, finally, a democraticnon-liberal state to exist. Secondly, democracy and liberalism are antithetical to each other, which means that these concepts are mutually exclusive (this type of relationship is promoted by both conservative liberals and radical democrats). Thirdly, finally, democracy and liberalism appear in a relationship of need, which means that only democracy can realize liberal ideals and, on the other hand, only

38 For more, see: J. Przedańska, "Ab ovo: czyli o koncepcji państwa prawa”, [in:] Administracja publiczna pod rzadami prawa. Księga pamiatkowa z okazji 70-lecia urodzin prof. zw. dra hab. Adama Btasia, ed. J. Korczak, Wrocław 2016, pp. 393-407.

39 This is how Robert Dahl (R. Dahl, Demokracja i jej krytycy, Warszawa 2012) and Giovanni Sartori write, according to whom contemporary political democracy coincides with liberalism and cannot be separated from it - G. Sartori, Teoria demokracji, Warszawa 1994, p. 475 ff. Ofer Raban also claims the same, writing that "The identification of democracy with liberal democracy is so common that it often seems to be adopted as a working assumption" [own translation] — O. Raban, "Racjonalizacja polityki: o związku między demokracją a rządami prawa", Ruch Prawniczy, Ekonomiczny i Socjologiczny 4, 2014, p. 23.

${ }^{40}$ H. Izdebski, Fundamenty współczesnych państw, Warszawa 2007, p. 74 ff. See also: H. Izdebski, "Totalitaryzm i terminy pokrewne w naukach społecznych oraz w polskim języku prawnym i prawniczym", Studia nad Autorytaryzmem i Totalitaryzmem 38, 4, 2016, no. 4, pp. 31-42.

${ }^{41}$ F.A. Hayek, op. cit., pp. 112-116. 
a liberal state provides the conditions for democracy to function. ${ }^{42}$ However, it should be added that $\mathrm{N}$. Bobbio himself advocates a close relationship between liberalism and democracy, which democracy fills and makes real. ${ }^{43}$

Andrzej Antoszewski points out that the conclusions from the so-called third wave of democratization ${ }^{44}$ do not necessarily support Samuel P. Huntington's thesis that countries rejecting consolidated authoritarianism unequivocally accept the principles of liberal democracy. On the contrary, the author notes that, for countries without a consolidated liberal democracy, the concept of non-liberal democracy proves to be an alternative, which, on the one hand, is promoted as restoring the sense of democracy and, on the other, provides mechanisms for building closer relations and ties between those being governed and those who govern, which, in turn, translates into greater effectiveness of the authority. ${ }^{45}$

The term 'non-liberal democracy' is relatively new; it is linked to Fareed Zakaria's publication in $1997,{ }^{46}$ whereas it penetrated the language of politics through the speech of Hungarian Prime Minister Victor Orban in 2012. Interestingly, various names have been adopted in the academic and journalistic discourse to describe the system of a state that is clearly not a liberal democracy, but still (although it may sometimes be) not an autocratic one, namely so-called hybrid regimes, such as 'non-liberal democracy', 'anti-liberal democracy', 'totalitarian democracy', 'incomplete democracy', 'limited democracy', 'delegated democracy', 'imitative democracy', 'populist democracy', 'managed democracy', 'semi-democracy', 'delegated democracy', as well as 'semi-authoritarian regime', 'competitive authoritarianism', 'managed pluralism', 'dominant authority regime' and 'soft totalitarianism' ${ }^{47}$ These are by no means synonymous terms, but they define a whole range of solutions that unequivocally criticize (or reject, and if so, more often than not, in a concealed way) the demands of a liberal state, namely broadly understood

42 N. Bobbio, Liberalizm i demokracja, Kraków-Warszawa 1998, pp. 35-36.

43 This is because N. Bobbio writes that: "Democracy will prove to be not only commensurate with liberalism, but also its natural continuation - if we were to consider not its egalitarian ideals but the political formula, which is, as we have seen, the sovereignty of the people. The only way in which this authority can take on a real dimension is to grant as many citizens as possible the right to participate directly and indirectly in collective decision making" [own translation] N. Bobbio, op. cit., p. 28.

44 S.P. Huntington, Trzecia fala demokratyzacji, Warszawa 2009; A. Skorupka, "Demokratyzacja świata według Samuela Huntingtona”, Rocznik Filozoficzny Ignatianum 2, 2016, pp. 206-221.

45 A. Antoszewski, "Demokracja nieliberalna jako projekt polityczny", Przegląd Europejski 2, 2018, pp. 12.

${ }^{46}$ F. Zakaria, "The rise of illiberal democracy", Foreign Affairs 6, 1997; I. Krastev, "Eastern Europe's illiberal revolution: The long road to democratic decline", Foreign Affairs 3, 2018; A. Buzogány, "Illiberal democracy in Hungary: Authoritarian diffusion or domestic causation?", Democratization 7, 2017.

47 Cf. M. Prokop, "Demokratyczno-autorytarna hybryda: redefinicja kategorii teoretycznej”, Historia i Polityka 13, 2015, pp. 31-46. 
protection of freedoms and civil rights, the idea of the rule of law (separation of powers), the recognition of minority rights, or the acceptance of pluralism.

Interestingly, political leaders who refer to the concept of non-liberal democracy do not directly deny the rule of law or directly call for the breach of civil rights. ${ }^{48}$ On the contrary, they propose a reinterpretation of the rules of the political game in the name of improving existing democracy, which often leads to a complete change. ${ }^{49}$ However, it is characteristic that reforms and the repair of the 'depraved' mechanisms of a liberal democracy are declared, ${ }^{50}$ without revealing the real objectives associated with restricting the rights and freedoms of citizens in favour of increasing the scope of authority, in which the classic divisions between the legislative and executive dimensions and, in time, the judiciary are no longer relevant.

The main problems of democratic systems are related to the assumption that democracy does not need legitimacy, that democracy itself is the source and tool which such legitimacy creates and safeguards.$^{51}$ This is a classic case of the paradox of democracy, which Karl R. Popper was the first to name and diagnose. ${ }^{52}$ In connection with this paradox, A. Chmielewski notes that the fact that regular elections are organized does not at all prejudge the functioning of democracy in a given country, because various regimes which have nothing to do with democracy do this. Increasingly, more countries are governed by groups and individuals who have been given a mandate to govern through general elections, while some of them are despotic countries that need the staffage of a democratic choice as the legitimacy of their authority. However, sometimes, when exercising their power, political entities dismantle democratic institutions (independent judiciary, independent media, etc.) in the name of the restoration of democracy, justifying such actions by the democratic consent and approval of their electorate: anti-democratic actions have democratic legitimacy. ${ }^{53}$

48 Cf. S. Repucci, "Freedom in the World 2020. A Leaderless Struggle for Democracy", Freedom House, https://freedomhouse.org/report/freedom-world/2020/leaderless-struggle-democracy (accessed: 26.11.2020).

49 A. Antoszewski, op. cit., pp. 13-14.

50 See also Ł. Kołtuniak, "Nieliberalna demokracja a państwo prawa. Przypadek Węgier Wiktora Orbana”, Internetowy Przeglad Prawniczy TBSP UJ 8, 2017, pp. 172-180.

51 As Bogdan Szlachta emphasizes, recalling Aristotle's thought, it is not the will of the people that is important, but the will of those to whom the people have subordinated themselves (Aristotle, Polityka, p. 1292a ff.); this remark is all the more important — as the author emphasizes because it reflects a peculiar 'transfer' of the source of resolutions from the 'collective entity' that formally adopts them to the real entity that influences or shapes the content of the will expressed in the resolutions — see: B. Szlachta, "Liberalna demokracja jako obóz koncentracyjny? Kilka uwag o mnożących się (skandalicznych?) opiniach", Studia nad Autorytaryzmem i Totalitaryzmem 38, 2016, no. 4, p. 58.

52 K.R. Popper, Społeczeństwo otwarte i jego wrogowie, vol. 1, Warszawa 1993, pp. 144-146.

53 Cf. A. Chmielewski, “Czyj liberalizm? Jaka demokracja?”, Odra 4, 2018, p. 15-19. 
Furthermore, it is characteristic that, while within a liberal state, the key element of individualism according to which a society is made up of individuals forming a political community in order to gain individual benefits and protect freedom, the non-liberal state is intended to serve the common good and the 'common truth, ${ }^{54}$ which by its very nature sanctions the restriction or even denial of individual freedoms, including the freedom of (national, religious, sexual etc.) minorities.

It is also worth noting that the concept of totalitarian democracy ${ }^{55}$ took root as early as the $1950 \mathrm{~s}$, which, according to Jacob L. Talmon, can be contrasted with liberal democracy. ${ }^{56}$ However, in an attempt to grasp the essence of totalitarian democracy, he distinguished three of its key elements: firstly, collectivism, which is the opposite of an individual approach; secondly, teleological monism, which is built on a hegemonic ideology; thirdly, the abolition of the boundary between the public sphere and the private sphere. ${ }^{57}$

J.L. Talmon claimed - most importantly for the considerations presented in this article - that it cannot be said that liberal democracy upholds freedom, while totalitarian democracy negates freedom. On the contrary, he believed that these two types of democracy have a different view of freedom. Firstly, freedom in a liberal democracy is a dominant feature that is legally protected from external coercion of the individual, while freedom in a totalitarian democracy is related to a unitary (uniform, homogeneous) community (collective), which is in control of the common will. Secondly, in the teleological dimension, a different perception of freedom is associated with a different approach to politics itself; while liberal democracy is characterized by a diversity of attitudes in politics and of individual and collective levels, which remain outside the sphere of politics, totalitarian democracy assumes the existence of a single truth in politics, even described as a kind of political messianism, which suppresses a harmonious and predetermined order of things or values, while not allowing any individual or collective acts having certain social features - to function outside the order of political acts. ${ }^{58}$

With such a distinction, the question can be asked as to whether there is really room for exercising individual freedoms in an illiberal state, in which freedom is linked to a homogeneous community with a common will, if they do not conform to the 'truth' imposed from above? Is it true, as, for instance, J.L. Talmon or A. MacIntyre wrote, that, in a country that rejects liberal principles, there can be

54 Cf. A. Puddington, Breaking down democracy: Goals, strategies, and methods of modern authoritarians, June 2017, https://freedomhouse.org/sites/default/files/June2017_FH_Report_Bre aking_Down_Democracy.pdf (accessed: 11.12.2020).

$\overline{55}$ Cf. R. Tokarczyk, "Demokracja a dyktatura, autorytaryzm, totalitaryzm. Komparatystyka relacji czterech pojęć', 'Studia nad Autorytaryzmem i Totalitaryzmem' 30, 2008, pp. 7-34.

56 For more, see: N. Slenzok, "Problem demokracji totalitarnej w filozofii politycznej libertarianizmu”, 'Studia nad Autorytaryzmem i Totalitaryzmem' 40, 2018, no. 2 pp. 5-23.

57 J.L. Talmon, Źródła demokracji totalitarnej, Kraków 2015, p. 39 ff. Cf. N. Slenzok, op. cit., pp. 7-8.

58 J.L. Talmon, op. cit., pp. 9-10. 
no talk of a lack of freedom, although the development of the individual subjectivity of people is subordinated to the supra-individual political objectives of the community to which they belong? The practice of operation of countries described as non-liberal democracies shows something completely different. ${ }^{59}$ The authors correctly diagnose the situation of restricting freedom in non-liberal countries in the report prepared for The Brookings Institution, noting that non-liberal political parties and leaders are increasingly easily implementing institutional reforms which restrict civic freedoms, the protection of minorities and human rights, the freedom of the press, the independence of the judiciary and, therefore, an open civic society. At the same time, these leaders define national identity, which they contrast with certain 'dangerous external groups' (e.g. immigrants or supranational institutions, such as the EU), to restore national rights to sovereignty, so as to compensate for historical wrongs. ${ }^{60}$

\section{Conclusion}

The assumptions of a liberal state and an illiberal state are not the main bone of contention; although the political project of an illiberal democracy arises from the criticism of liberalism, their polarization is considered to be methodologically wrong. While the construction and consolidation of a liberal democracy is and can be the ultimate target for many countries, the functioning of a state of non-liberal democracy is always only a transitional state. ${ }^{61}$ A. Antoszewski and R. Herbut, who point out that countries remain in a 'zone of non-liberal democracy' in principle, only temporarily although this stay may be extended, make a good point. In their opinion, political evolution can transform such a country into either a strictly democratic or authoritarian nation, while the factor that determines the direction of political development of countries in an illiberal democracy is the will of an indi-

59 See: T. Drinóczi, A. Bień-Kacała, "Illiberal constitutionalism: The case of Hungary and Poland", German Law Journal 20, 2019, pp. 1140-1166; R.S. Foa, Y. Mounk, "The danger of deconsolidation", Journal of Democracy 3, 2016, pp. 5-17; H. Eissenstat, Erdoğan as Autocrat: A Very Turkish Tragedy, Washington, DC, April 2017, pp. 11-12, http://pomed.org/wp-content/ uploads/2017/04/Erdoğan_as_autocrat.pdf(accessed: 5.12.2020); N. Buckley, H. Foy, "Poland's new government finds a model in Orban's Hungary", Financial Times 6.01.2016, https://www.ft.com/ content/0a3c7d44-b48e-11e5-8358-9a82b43f6b2f (accessed: 8.12.2020); A. Innes, "Hungary's illiberal democracy”, Current History 770, 2015, pp. 95-100; A. Szymański, “Zmierzch demokracji liberalnej? Turcja oraz państwa Europy Środkowej i Wschodniej w perspektywie porównawczej”, [in:] Zmierzch demokracji liberalnej?, eds. K.A. Wojtaszczyk, P. Stawarz, J. Wiśniewska-Grzelak, Warszawa 2018, pp. 237-251.

60 A. Polyakova et al., The Anatomy of Illiberal States: Assessing and Responding to Democtratic Decline in Turkey and Central Europe, Foreign Policy at Brookings, February 2019, https:// www.brookings.edu/wp-content/uploads/2019/02/illiberal-states-web.pdf (accessed: 25.11.2020), p. 7 ff.

61 Cf. M. Prokop, op. cit., pp. 39, 46. 
vidual or a small group which does not face any serious limitations, or unpredictable events. ${ }^{62}$ However, this does not change the fact that the state of an illiberal democracy can be long-term.

Every attempt to become unified, uniform and egalitarian is related to a violation of freedom ${ }^{63}$; there is no doubt about that today. A (programming, ideological, moral, etc.) unity which is imposed like a dogma is a unity that does not respect the diversity of individual subjectivities and freedoms and, consequently, restricts and closes public spaces, ensuring that there is no longer any room in them for new ways of exercising freedom of the individual. Non-liberal democracy, using the communitarian concept of community, which is definitely missing from the dictionary of liberals, ${ }^{64}$ aims to ensure the unity of this community, ${ }^{65}$ which is intended to be a guarantor of the achievement of the objectives of the political entity, and treats the freedoms and rights of the citizen as if they were directed against this community. Alongside the populist attitude of those in power, the failure to observe the principle of checks and balances and the relativization of the rule of law, a fundamental distinction of this political project is the desire to restrict the freedom of the individual.

Illiberal democracy, as opposed to open authoritarianism, mobilizes social resistance to a much lesser extent, because it is more difficult for the electorate to see the relativization and restriction of its freedom, as a sense of collective freedom is being built. ${ }^{66}$ In conclusion, it is worth quoting the words of Michael Sandel, ${ }^{67}$ who aptly stated that if a community, represented in parliament by a democratically elected majority, receives the right to decide what is a value and what is not, and which freedoms are worth granting and which freedoms should be restricted,

62 A. Antoszewski, R. Herbut, Systemy polityczne współczesnego świata, Gdańsk 2006, pp. 190-192; A. Antoszewski, op. cit., p. 26.

63 Cf. e.g. M. Markiewicz, "Wspólnota, czyli jedność: posthumanizm i brak tolerancji”, Fragile. Pismo Kulturalne 1, 2016, pp. 12-16.

64 As A. Chmielewski notes: "The absence of the idea of a community in most variants of liberalism is responsible for the tension between liberalism and the people and for the crisis of contemporary politics. In most versions of the liberal doctrine, the place of the forgotten values and community relations is occupied by individualistic, privately understood property. Its prominent role in liberalism a reason of no less importance to the tension between liberalism and democracy. Therefore, the cause of the current political crisis is not democracy understood as a package of formalized institutions, but precisely liberalism, which, in symbiosis with procedural democracy, has destroyed these lively social relations and the sense of the common good, while it has privatized the common good itself” — A. Chmielewski, "Czyj liberalizm?...”, p. 18.

${ }^{65}$ K.R. Popper rightly stated that only guaranteed religious, cultural and social pluralism contributes to the acceptance of the community and the desire to belong to it - see: K.R. Popper, op. cit., p. $186 \mathrm{ff}$.

${ }^{66}$ Cf. P. Malendowicz, "Symptomaty antydemokratyzmu w myśli politycznej i aktywności partii radykalnie nacjonalistycznych w Europie na początku XXI wieku. Analiza wybranych przykładów", Studia nad Autorytaryzmem i Totalitaryzmem 42, 2020, no. 1, pp. 65-66.

67 M. Sandel, Democracy's discontent, Harvard 1996, pp. 317-320. 
then that community will become a tool for subjugating minorities and imposing the values in which the majority believes on those minorities.

\section{Bibliography}

Acton J., Historia wolności. Wybór esejów, Kraków 1995.

Amsterdamski S., "O różnych pojęciach determinizmu”, Studia Filozoficzne 2, 1964.

Antoszewski A., "Demokracja nieliberalna jako projekt polityczny", Przeglad Europejski 2, 2018.

Antoszewski A., Herbut R., Systemy polityczne współczesnego świata, Gdańsk 2006.

Aristotle, Dzieła wszystkie, vol. 6, Warszawa 2001.

Bakunin M.A., Pisma wybrane, vol. 1 and 2, Warszawa 1965.

Berlin I., Cztery eseje o wolności, Warszawa 1994.

Bobbio N., Liberalizm i demokracja, Kraków-Warszawa 1998.

Buckley N., Foy H., "Poland's new government finds a model in Orban's Hungary", Financial Times, 6.01.2016, https://www.ft.com/content/0a3c7d44-b48e-11e5-8358-9a82b43f6b2f (accessed: 8.12.2020).

Buzogány A., "Illiberal democracy in Hungary: Authoritarian diffusion or domestic causation?", Democratization 7, 2017.

Chmielewski A., Dwie koncepcje jedności. Interwencje filozoficzno-polityczne, Wrocław 2006.

Chmielewski A., Społeczeństwo otwarte czy wspólnota? Filozoficzne i moralne podstawy nowoczesnego liberalizmu oraz jego krytyka we współczesnej filozofii politycznej, Wrocław 2001.

Chmielewski A., "Czyj liberalizm? Jaka demokracja?”, Odra 4, 2018.

Constant B., O monarchii konstytucyjnej i rękojmiach publicznych, Warszawa 2016.

Dahl R., Demokracja i jej krytycy, Warszawa 2012.

Determinizm, przypadek, wolność, ed. A. Wójtowicz, Poznań 2005.

Dominiak Ł., Wartość wspólnoty. O filozofii politycznej komunitaryzmu, Torun 2010.

Drinóczi T., Bień-Kacała A., "Illiberal constitutionalism: The case of Hungary and Poland", German Law Journal 20, 2019.

Eissenstat H., Erdoğan as Autocrat: A Very Turkish Tragedy, Washington, DC, April 2017, http:// pomed.org/wp-content/uploads/2017/04/Erdoğan_as_autocrat.pdf (accessed: 5.12.2020).

Filozofia a nauka. Zarys encyklopedyczny, Wrocław 1987.

Repucci S., "Freedom in the World 2020. A Leaderless Struggle for Democracy", Freedom House, https://freedomhouse.org/report/freedom-world/2020/leaderless-struggle-democracy (accessed: 26.11.2020).

Foa R.S., Mounk Y., “The danger of deconsolidation”, Journal of Democracy 3, 2016.

Friedmann M., Free to Choose, New York 1980.

Fromm E., Ucieczka od wolności, Warszawa 2014.

Gray J., "On positive and negative freedom", [in:] Conceptions of Liberty in Political Philosophy, eds. J. Gray, Z. Pełczyński, London 1984.

Gray T., Freedom, London 1990.

Hayek F.A. von, Konstytucja wolności, Warszawa 2006.

Hindess B., Filozofie władzy. Od Hobbesa do Foucaulta, Warszawa 1999.

Huntington S.P., Trzecia fala demokratyzacji, Warszawa 2009.

Innes A., "Hungary's illiberal democracy", Current History 770, 2015.

Izdebski H., Fundamenty wspótczesnych państw, Warszawa 2007.

Izdebski H., "Totalitaryzm i terminy pokrewne w naukach społecznych oraz w polskim języku prawnym i prawniczym”, Studia nad Autorytaryzmem i Totalitaryzmem 38, 2016, no. 4. 
Jeż G., "Idea sprawiedliwości społecznej jako kamuflaż sprawiedliwości rozdzielczej i jej krytyka w myśli Friedricha Augusta von Hayeka", Kwartalnik Historii Myśli Ekonomicznej 1, 2014.

Kant I., Krytyka praktycznego rozumu, Warszawa 2004.

Kołtuniak Ł., "Nieliberalna demokracja a państwo prawa. Przypadek Węgier Wiktora Orbana", Internetowy Przeglad Prawniczy TBSP UJ 8, 2017.

Kowalewski Z., "Społeczeństwo obywatelskie a 'politeia' i 'res publica”, Studia Filozoficzne 9, 1987.

Krastev I., "Eastern Europe's illiberal revolution: The long road to democratic decline", Foreign Affairs 3, 2018.

Kukathas Ch., "Wolność”, [in:] Przewodnik po wspótczesnej filozofii politycznej, eds. R.E. Goodin, P. Pettit, Warszawa 1998.

Lamentowicz W., O wolnościach i ich granicach, http://www.academia.edu/1136811/Granice_wolności (accessed: 10.12.2020).

Locke J., Dwa traktaty o rzadzie, Warszawa 1992.

MacCallum G.C., "Negative and positive freedom", The Philosophical Review 3, 1967.

MacIntyre A., Dziedzictwo cnoty. Studium z teorii moralności, Warszawa 1996.

Malendowicz P., "Symptomaty antydemokratyzmu w myśli politycznej i aktywności partii radykalnie nacjonalistycznych w Europie na początku XXI wieku. Analiza wybranych przykładów", Studia nad Autorytaryzmem i Totalitaryzmem 42, 2020, no. 1.

Markiewicz M., "Wspólnota, czyli jedność: posthumanizm i brak tolerancji”, Fragile. Pismo Kulturalne 1, 2016.

Morawski L., Główne problemy współczesnej filozofii prawa. Prawo w toku przemian, Warszawa 2005.

Mrozowska S., "Wolność negatywna w warunkach demokracji liberalnej”, [in:] Paradoksy liberalizmu, eds. D. Karnowska, A. Modrzejewski, Toruń 2009.

Nowicki Ś.F., "Heglowskie pojęcie społeczeństwa obywatelskiego", Studia Filozoficzne 9, 1987.

Nozick R., Anarchia, państwo, utopia, Warszawa 1999.

Pettit P., "The freedom of the city: A republican ideal", [in:] The Good Polity. Normative Analysis of the State, eds. A. Hamlin, P. Pettit, Oxford 1989.

Pietrzyk-Reeves D., Idea społeczeństwa obywatelskiego. Współczesna debata i jej źródła, Wrocław 2004.

Polanowska-Sygulska B., Oblicza liberalizmu, Kraków 2003.

Polyakova A. et al., The Anatomy of Illiberal States: Assessing and Responding to Democtratic Decline in Turkey and Central Europe, Foreign Policy at Brookings, February 2019, https://www. brookings.edu/wp-content/uploads/2019/02/illiberal-states-web.pdf (accessed: 25.11.2020).

Popper K.R., Społeczeństwo otwarte i jego wrogowie, t. 1, Warszawa 1993.

Prokop M., "Demokratyczno-autorytarna hybryda: redefinicja kategorii teoretycznej”, Historia i Polityka 13, 2015.

Przedańska J., "Ab ovo: czyli o koncepcji państwa prawa”, [in:] Administracja publiczna pod rzadami prawa. Księga pamiatkowa z okazji 70-lecia urodzin prof. zw. dra hab. Adama Btasia, ed. J. Korczak, Wrocław 2016.

Przedańska J., "Równość w wolności — między komunitaryzmem a liberalizmem”, [in:] Wolność w prawie administracyjnym, ed. J. Zimmermann, Warszawa 2017.

Przedańska J., "Społeczeństwo obywatelskie jako idea filozoficzna", [in:] Prawna działalność instytucji społeczeństwa obywatelskiego, eds. J. Blicharz, J. Boć, Wrocław 2009.

Przybysz P., "Dwa modele człowieka. O sporze liberalizm-komunitaryzm", Arka 3, 1994.

Puddington A., Breaking down democracy: Goals, strategies, and methods of modern authoritarians, June 2017, https://freedomhouse.org/sites/default/files/June2017_FH_Report_Breaking_ Down_Democracy.pdf (accessed: 11/12/2020).

Raban O., "Racjonalizacja polityki: o związku między demokracją a rządami prawa", Ruch Prawniczy, Ekonomiczny i Socjologiczny 4, 2014. 
Rau Z., Zapomniana wolność. W poszukiwaniu historycznych podstaw liberalizmu, Warszawa 2008. Rawls J., Teoria sprawiedliwości, Warszawa 2009.

Rousseau J.J., Umowa społeczna, Łódź 1948.

Rozen Ł., "Liberalizm i demokracja jako fundamentalny dylemat współczesnej polityki", [in:] Zmierzch demokracji liberalnej?, eds. K.A. Wojtaszczyk, P. Stawarz, J. Wiśniewska-Grzelak, Warszawa 2018.

Sandel M., Democracy's discontent, Harvard 1996.

Sartori G., Teoria demokracji, Warszawa 1994.

Sartre J.P., "Absolutna wolność bytu ludzkiego", [in:] Filozofia egzystencjalna, eds. L. Kołakowski, K. Pomian, Warszawa 1965.

Siemek M.J., Hegel i filozofia, Warszawa 1998.

Sienkiewicz G.W., Egalitaryzm demokratyczny. Podstawy teorii sprawiedliwości Johna Rawlsa, Toruń 2008.

Skinner Q., "The paradoxes of political liberty”, [in:] Liberty, ed. D. Miller, Oxford 1991.

Skorupka A., "Demokratyzacja świata według Samuela Huntingtona", Rocznik Filozoficzny Ignatianum 2, 2016.

Slenzok N., "Problem demokracji totalitarnej w filozofii politycznej libertarianizmu", Studia nad Autorytaryzmem i Totalitaryzmem 40, 2018, no. 2.

Steiner H., "How free: Computing personal liberty", [in:] Of Liberty, ed. A. Phillips Griffiths, Cambridge 1983.

Szacki J., "Od polis do społeczeństwa obywatelskiego", [in:] J. Szacki, Historia myśli socjologicznej, Warszawa 2005.

Szahaj A., "Jednostka czy wspólnota", [in:] Liberalizm u schyłku XX wieku, ed. J. Miklaszewska, Kraków 1999.

Szlachta B., "Liberalna demokracja jako obóz koncentracyjny? Kilka uwag o mnożących się (skandalicznych?) opiniach", Studia nad Autorytaryzmem i Totalitaryzmem 38, 2016, no. 4.

Szymański A., "Zmierzch demokracji liberalnej? Turcja oraz państwa Europy Środkowej i Wschodniej w perspektywie porównawczej”, [in:] Zmierzch demokracji liberalnej?, eds. K.A. Wojtaszczyk, P. Stawarz, J. Wiśniewska-Grzelak, Warszawa 2018.

Śleziński K., "Determinizm i indeterminizm w dyskusji metanaukowej połowy XX wieku", Bielsko-Żywieckie Studia Teologiczne 4, 2003.

Talmon J.L., Źródła demokracji totalitarnej, Kraków 2015.

Tam H.B., Komunitaryzm. Nowy program polityczny i obywatelski, Torun 2011.

Tatarkiewicz W., Historia filozofii, vol. 3, Warszawa 2003.

Taylor Ch., Etyka autentyczności, Kraków 1996.

Tokarczyk R., "Demokracja a dyktatura, autorytaryzm, totalitaryzm. Komparatystyka relacji czterech pojęć", Studia nad Autorytaryzmem i Totalitaryzmem 30, 2008.

Turowski M., Liberalizm po komunitaryzmie? Filozoficzne koncepcjejednostki, wspólnoty i państwa jako źródta krytyki społecznej i politycznej, Toruń 2011.

Unger R.M., Ruch studiów krytycznych nad prawem, Warszawa 2005.

Wonicki R., Spór o demokratyczne państwo prawa. Teoria Jürgena Habermasa wobec liberalnej, republikańskiej i socjalnej wizji państwa, Warszawa 2007.

Zakaria F., "The rise of illiberal democracy", Foreign Affairs 6, 1997.

Zdybel J., Między wolnością a powinnością. Filozofia polityczna Isaiaha Berlina i Alasdaira MacIntyre'a, Lublin 2005.

Žižek S., Przekleństwo fantazji, Wrocław 2001.

Żelazny M., Idea wolności w filozofii Kanta, Toruń 2001.

Studia nad Autorytaryzmem i Totalitaryzmem 43, nr 1, 2021

(C) for this edition by CNS 